\title{
Steroid responsive polyneuropathy in a family with a novel myelin protein zero mutation
}

\author{
M Donaghy, S M Sisodiya, R Kennett, B McDonald, N Haites, C Bell
}

\begin{abstract}
Objective-To report a novel hereditary motor and sensory neuropathy (HMSN) phenotype, with partial steroid responsiveness, caused by a novel dominant mutation in the myelin protein zero (MPZ) gene. Most MPZ mutations lead to the HMSN type I phenotype, with recent reports of Déjérine-Sottas, congenital hypomyelination, and HMSN II also ascribed to MPZ mutations. Differing phenotypes may reflect the effect of particular mutations on $M P Z$ structure and adhesivity.
\end{abstract}

Methods-Clinical, neurophysiological, neuropathological, and molecular genetic analysis of a family presenting with an unusual hereditary neuropathy.

Results-Progressive disabling weakness, with positive sensory phenomena and areflexia, occurred in the proband with raised CSF protein and initial steroid responsiveness. Nerve biopsy in a less severely affected sibling disclosed a demyelinating process with disruption of compacted myelin. The younger generation were so far less severely affected, becoming symptomatic only after 30 years. All affected family members were heterozygous for a novel MPZ mutation (Ile99Thr), in a conserved residue.

Conclusions-This broadens the range of familial neuropathy associated with $M P Z$ mutations to include steroid responsive neuropathy, initially diagnosed as chronic inflammatory demyelinating polyneuropathy.

(F Neurol Neurosurg Psychiatry 2000;69:799-805)

Keywords: myelin protein $\mathrm{P}_{0}$; hereditary motor and sensory neuropathy; steroid responsive polyneuropathy

Charcot-Marie-Tooth disease, also known as hereditary motor and sensory neuropathy (HMSN), is a clinically and genetically heterogeneous group of peripheral nerve disorders. ${ }^{1}$ Pathological alterations in a number of genes, PMP22, connexin-32, and $M P Z$ (myelin protein zero $\left(\mathbf{P}_{0}\right)$ ), account for some of the various phenotypes. $P_{0}$ is the dominant transmembrane glycoprotein in peripheral myelin, and is a member of the immunoglobulin superfamily. ${ }^{2}$ The various $\mathrm{P}_{0}$ mutations produce differing clinical syndromes. Mutations in $\mathrm{P}_{0}$ usually cause a subgroup of Charcot-Marie-Tooth disease characterised by nerve conduction velocities below $38 \mathrm{~m} / \mathrm{s}$ (HMSN IB), and $\mathrm{P}_{0}$ mutations have also been found in cases of Déjerine-Sottas disease and congenital hypomyelination. ${ }^{3-14}$ Recently, $P_{0}$ mutations have been found in two families with the clinical and electrophysiological syndrome of HMSN II, the neuronal form of CharcotMarie-Tooth disease, thereby spreading the range of phenotypes beyond demyelinating and hypomyelinating neuropathies. ${ }^{15} 16$

We report on a family with a novel $\mathrm{P}_{0}$ mutation presenting with the unique features of late onset of a relatively mild neuropathy with positive sensory symptoms and variably slowed nerve conduction. The proband presented the clinical picture of chronic inflammatory demyelinating polyneuropathy (CIDP) and initially responded to steroid treatment. The family is considered in the light of previous reports of progressive worsening in hereditary neuropathy, the notion of steroid responsive HMSN, the predicted effect of the mutation, and recent findings from animal models.

\section{Methods}

SUBJECTS

The proband was referred for investigation of progressive disabling neuropathy. After the subsequent referral of two of his brothers for milder, similar symptoms, the rest of the pedigree was examined clinically and electrophysiologically and molecular genetic analysis of $P_{0}$ was undertaken.

\section{ELECTROPHYSIOLOGY}

Nerve conduction studies were performed on a Medelec Sapphire electromyograph by standard techniques using surface stimulating and recording electrodes. ${ }^{17}$

\section{NEUROPATHOLOGY}

A sural nerve biopsy was obtained from member $\mathrm{II}_{3}$. It was processed for routine light and electron microscopic studies.

\section{MOLECULAR GENETIC STUDIES}

Single stranded conformational polymorphism analysis and direct sequencing

The coding region of the $M P Z$ gene was amplified by polymerase chain reaction (PCR) using six primer sets as published by Nelis et al. ${ }^{18}$ Each amplification included $100 \mathrm{ng}$ genomic DNA, $200 \mu \mathrm{M}$ each of dATP, dGTP, and dTTP, $40 \mu \mathrm{M} \mathrm{dCTP}$, and $1.66 \mu \mathrm{Ci}^{32} \mathrm{P} \alpha \mathrm{dCTP}$, reaction buffer (10 $\mathrm{mM}$ Tris $\mathrm{HC} 1,50 \mathrm{mM}$ $\mathrm{KC} 1,0.001 \%$ gelatin (w/v)), $\mathrm{MgC1}_{2}$ as appropriate for each primer set, 10 pmol each upstream and downstream primer, 1 unit Taq DNA polymerase, and sterile distilled $\mathrm{H}_{2} \mathrm{O}$ to $25 \mu 1$. Amplification conditions were as follows: $94^{\circ} \mathrm{C}$ for 2 minutes, followed by 35 cycles of $94^{\circ} \mathrm{C}$ for 1 minute, $60^{\circ} \mathrm{C}$ for 2 minutes, $72^{\circ} \mathrm{C}$ for 2 minutes 30 seconds, and a final extension step of $72^{\circ} \mathrm{C}$ for 10 minutes using a Techne 


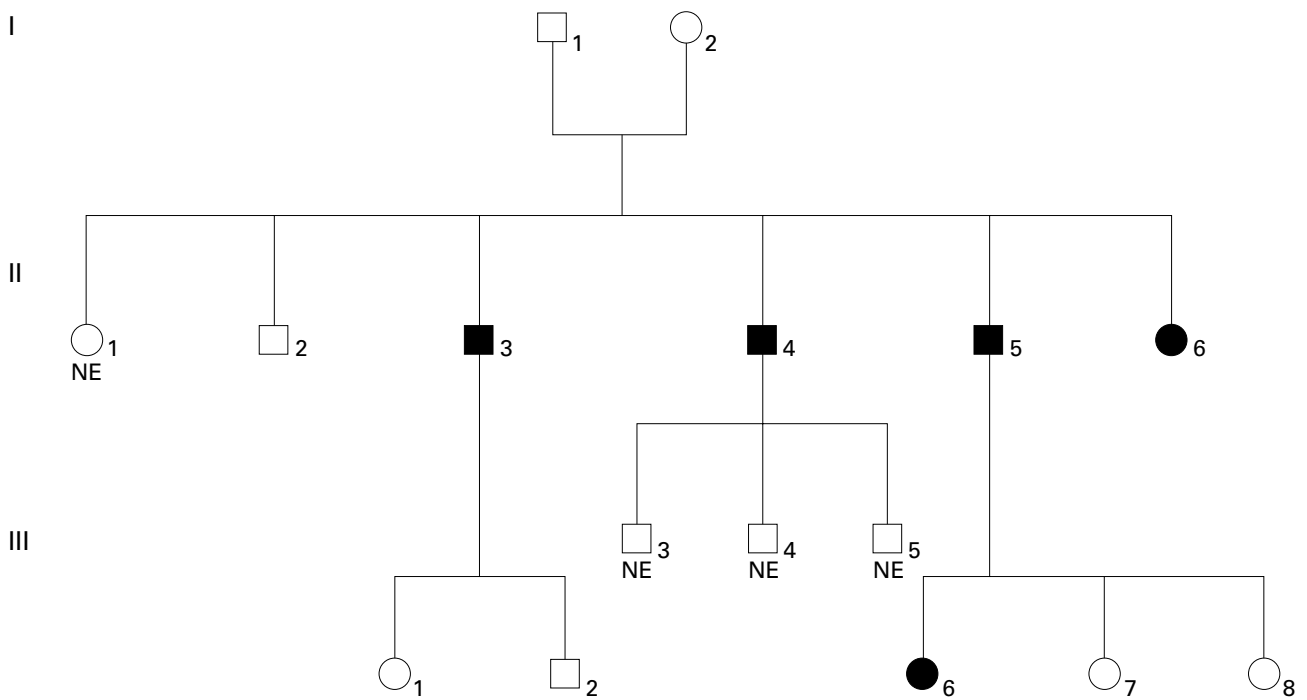

- Clinical and/or electrophysiological polyneuropathy $\mathrm{NE}=$ not examined

Figure 1 The pedigree.

PHC2 thermocycler. Products were then fractionated by electrophoresis in 5\% nondenaturing acrylamide gels and any sample showing altered mobility on autoradiography was selected, and the particular fragment reamplified as above using equimolar dNTPs (non-radioactively). Products were then purified using Centricon-100 columns (Amicon) and sequenced using the Taq dyedideoxy sequencing kit (ABI) both according to manufacturers' instructions. Sequencing products were fractionated by electrophoresis on an ABI377 automated sequencer, and analysed using the Sequence Editor programme (ABI).

\section{Restriction analysis}

Exon 3 of the $M P Z$ gene was amplified by PCR as for direct sequencing and an aliquot was subjected to SfaNI restriction digest according to the manufacturer's instructions. Restricted DNA was fractionated by electrophoresis in $2 \%$ agarose gels, stained in ethidium bromide, and visualised under UV light.

\section{Results}

CLINICAL FEATURES AND NERVE CONDUCTION STUDIES (FIG 1)

The previously asymptomatic proband $\left(\mathrm{II}_{5}\right)$, who was working delivering coal sacks, at the age of 58 developed leg weakness severe enough to prevent him from walking for several days after an upper respiratory tract illness. $\mathrm{He}$ never fully recovered, but was able to go back to work. Six months later the weakness worsened progressively for 5 months such that he had complete bilateral foot drop and was able to walk only 100 yards; upper limb weakness prevented work. He had developed tingling in his feet and hands. Examination showed an areflexic tetraparesis with loss of distal superficial and vibration sensitivity. His neurophysiological studies are shown in table 1 . On two occasions he showed a proximal to distal compound muscle action potential (CMAP) ratio from the right median nerve of $56 \%$ and the left median $\mathrm{F}$ responses were absent. The remaining nerves showed diffuse slowing of conduction velocity without conduction block

Table 1 Neurophysiology

\begin{tabular}{|c|c|c|c|c|c|c|c|c|c|c|c|c|c|c|c|}
\hline \multirow[b]{3}{*}{ Patient } & \multirow[b]{3}{*}{ Age } & \multicolumn{8}{|c|}{ Motor } & \multicolumn{6}{|c|}{ Sensory } \\
\hline & & \multicolumn{2}{|c|}{ Median } & \multicolumn{2}{|l|}{ Ulnar } & \multicolumn{2}{|c|}{ Peroneal } & \multicolumn{2}{|c|}{ Tibial } & \multicolumn{2}{|c|}{ Median } & \multicolumn{2}{|c|}{ Ulnar } & \multicolumn{2}{|l|}{ Sural } \\
\hline & & $A m p$ & $C V$ & $A m p$ & $C V$ & $A m p$ & $C V$ & $A m p$ & $C V$ & $A m p$ & $C V$ & $A m p$ & $C V$ & $A m p$ & $C V$ \\
\hline $\mathrm{II}_{5}$ * & 50 & 3.5 & 33 & 4.2 & 34 & 1.0 & 24 & 0.05 & 22 & 0 & & 0 & & 0 & \\
\hline $\mathrm{II}_{3}$ * & 59 & & & 11.0 & 41 & & & 1.4 & 30 & 1 & & 1 & & 0 & \\
\hline $\mathrm{II}_{4}^{\star}$ & 59 & 7.0 & 34 & 12.5 & 45 & 0.5 & 39 & & & 2 & 41 & 0 & & 0 & \\
\hline $\mathrm{II}_{6}{ }^{\star}$ & 54 & 15.5 & 51 & 18.5 & 54 & 0.8 & 32 & & & 5 & 45 & 6 & 46 & 0 & \\
\hline $\mathrm{III}_{4}$ & 37 & & & 20.0 & 64 & 2.5 & 42 & & & 18 & 53 & & & 22 & 52 \\
\hline $\mathrm{III}_{2}$ & 38 & 12.5 & 52 & & & 4.5 & 43 & & & 9 & 52 & & & 14 & 42 \\
\hline $\mathrm{III}_{6}^{2}$ * & 34 & 19.0 & 48 & 18.5 & 46 & 7.5 & 39 & & & 3 & 52 & 0 & & 5 & 31 \\
\hline $\mathrm{III}_{7}$ & 33 & 23.5 & 53 & & & 6.0 & 45 & & & 27 & 49 & 14 & 46 & 19 & 43 \\
\hline $\mathrm{III}_{8}$ & 32 & 30.0 & 52 & & & 20.0 & 46 & & & 14 & 50 & & & 13 & 35 \\
\hline
\end{tabular}

$\mathrm{CV}=$ Maximum conduction velocity in $\mathrm{m} / \mathrm{s} ; \mathrm{Amp}=$ peak to peak amplitude (in $\mathrm{mV}$ for motor and $\mu \mathrm{V}$ for sensory potentials); Laboratory normal values: conduction velocities in arms $>50 \mathrm{~m} / \mathrm{s}$; legs $>40 \mathrm{~m} / \mathrm{s}$.

Sensory nerve action potential amplitudes $>5 \mu \mathrm{V}$.

^ Patients with abnormal studies. 


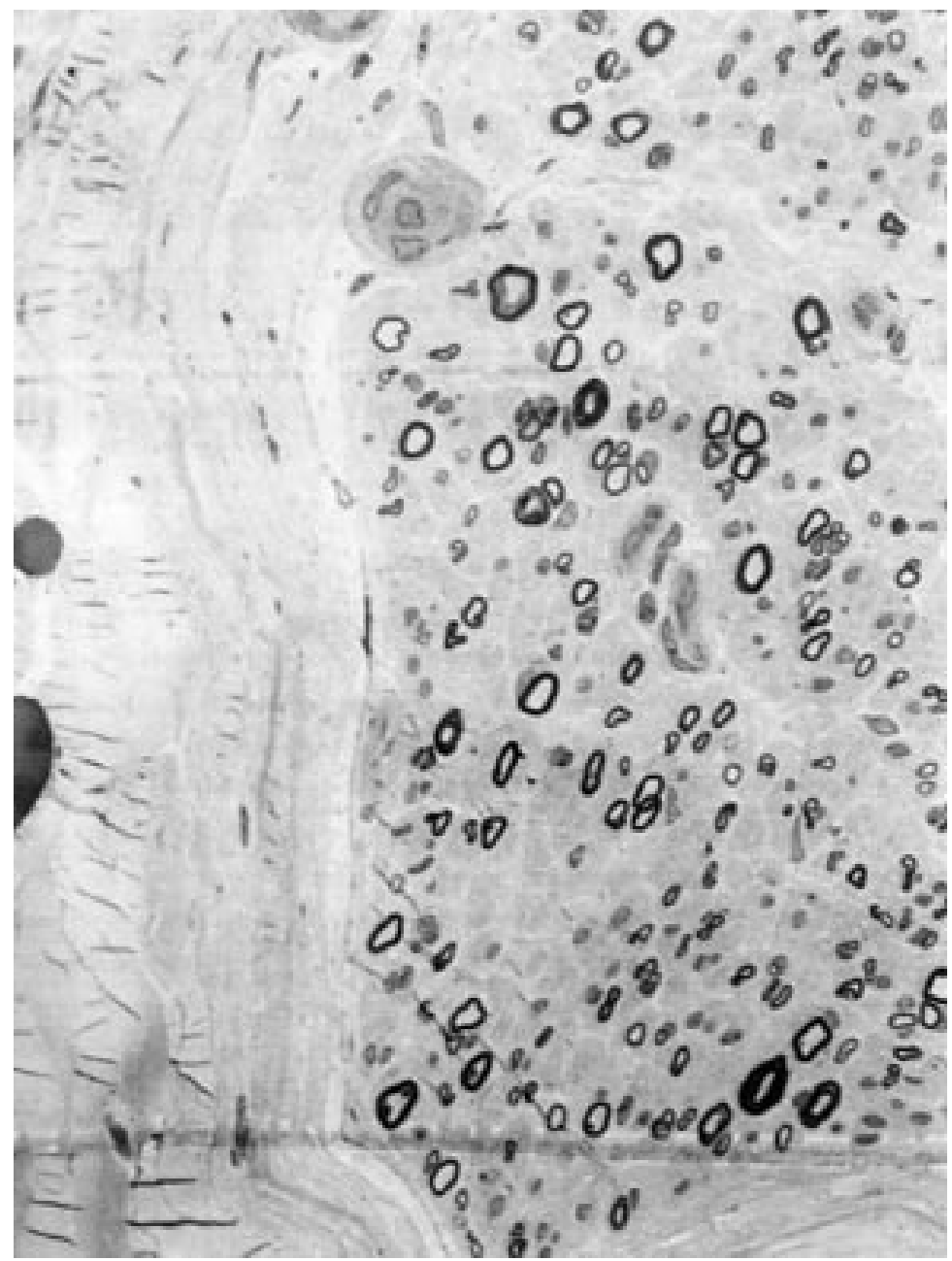

Figure 2 Resin embedded section $(1 \mu \mathrm{m})$ stained with toluidine blue, showing a reduction of density of myelinated axon fibres across the range of fibre diameters and extensive regenerative sprouting manifest by the clustering of thinly myelinated, mainly small fibres (magnification $\times 100$ ).

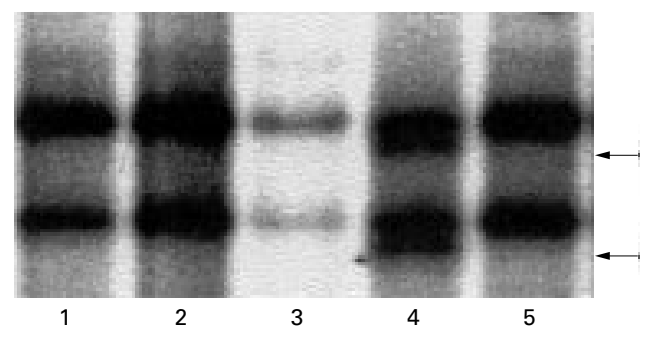

Figure 3 Mobility shift seen on SSCP analysis of exon 3 of the MPZ gene in individual II.3 (lane 4). Lanes 1-3 represent additional patients with HMSN. Lane 5 represents the mobility shift demonstrated by a normal control.

no upper limb weakness initially, but he later developed hand weakness, being unable to open bottles, and his walking distance decreased. His CSF protein was raised $(0.68 \mathrm{~g} / \mathrm{l})$, without pleocytosis. He underwent a sural nerve biopsy.

Patients $\mathrm{III}_{6}, \mathrm{III}_{7}$, and $\mathrm{III}_{8}$ (aged 32 to 34 ) were seen as part of the family study; all had paraesthesiae without weakness, areflexia, or sensory loss. All three had occasional positive sensory symptoms starting between the ages of 31 and 34 years. None of the patients with clinical, electrophysiological, or molecular genetic abnormalities showed pes cavus.

\section{NEUROPHYSIOLOGY}

Results are summarised in table 1 . In the right median nerve in the proband $\left(\mathrm{II}_{5}\right)$ only, compound muscle action potential amplitude fell from $2.5 \mathrm{mV}$ to $1.4 \mathrm{mV}$ between the elbow and the wrist; conduction velocity over this segment was $28 \mathrm{~m} / \mathrm{s}$. Repeat studies in the proband 9 years after initial presentation did not show significant progression. Patients $\mathrm{II}_{3}$ and $\mathrm{II}_{4}$ had more moderate slowing of conduction, with some preservation of sensory nerve action potentials (SNAPs). Patient $\mathrm{III}_{6}$ had borderline slowing of conduction and reduced SNAPs. These family members with slowing of motor velocity did not show conduction block or dispersion.

nerve stimulation. Protein in CSF was raised (0.72 g/l), without pleocytosis. A diagnosis of chronic inflammatory demyelinating polyneuropathy (CIDP) was made. After 4 months of treatment with $60 \mathrm{mg} /$ day prednisolone, there was marked improvement, with loss of hand paraesthesia; arm strength improved sufficiently to lift potato sacks and walking distance improved from 100 yards to over 1 mile. However, subsequent deterioration and steroid induced side effects necessitated trials of plasma exchange, azathioprine, intravenous immunoglobulin, and cyclosporin, without marked benefit.

The proband's brother $\left(\mathrm{II}_{4}\right)$, aged 59, was referred with a 2 year history of ascending leg paraesthesia and numbness. Examination showed absent ankle jerks, loss of vibration sense below the sternum, and reduced proprioception in the feet.

Patient $\mathrm{II}_{3}$, aged 61 , was referred with a 10 year history of foot numbness and lancinating pains, with recent unsteadiness and mild upper limb tremor. Examination showed mild upper limb action tremor, mild ankle dorsiflexion weakness, absent ankle jerks, and impairment of all sensory modalities in the feet. There was

\section{NEUROPATHOLOGY}

A $1.2 \mathrm{~cm}$ segment of sural nerve biopsy was obtained. Light microscopy showed chronic axonal neuropathy with attempted regeneration and without evidence of segmental myelin degeneration. The axonal damage was manifest as a moderate density reduction across the range of calibres of myelinated axon fibres (fig 2 ). Onion bulb regenerative clusters were absent and the appearance of teased nerve fibre preparations was normal. firmed chronic axonal degeneration with a reduction in myelinated axons, disruption of myelin compaction, a degree of axonal sprouting, and an increase in the endoneurial fibrous connective tissue component.

\section{MUTATION ANALYSIS}

SSCP analysis of the $M P Z$ coding region disclosed a mobility shift in members $\mathrm{II}_{5}$ and $\mathrm{II}_{4}$ when compared with unaffected control DNA (fig 3). Sequence analysis demonstrated a het-
Transmission electron microscopy con- 
A

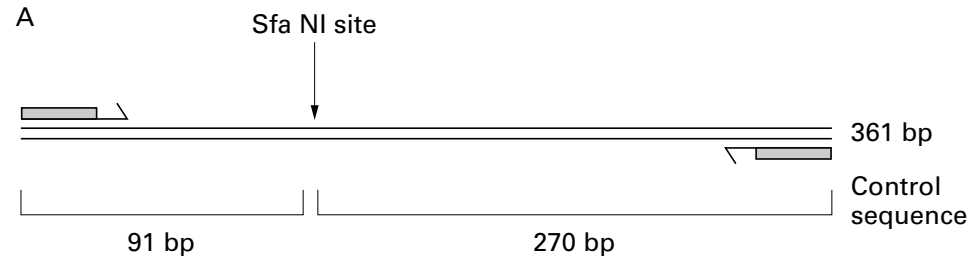

ATC > ACC destroys Sfa NI site

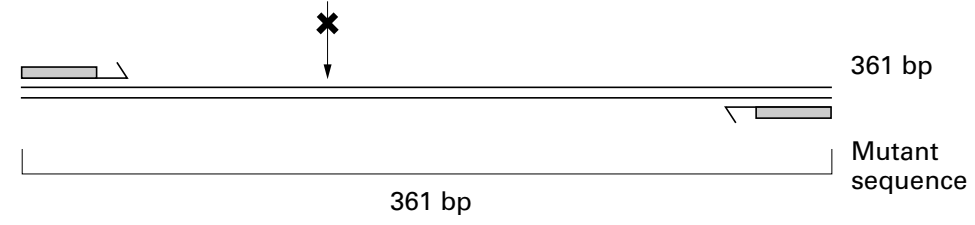

B

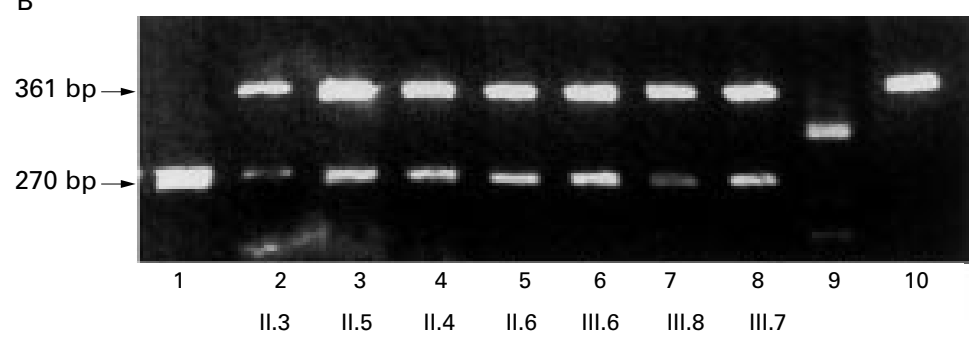

Figure 4(A) Schematic representation of the restriction site change resulting from the point mutation ( $A T C>A C C$ ) in codon 99 of the MPZ gene. Control sequence contains one SfaNI site and on restriction analysis produces two fragments of $270 \mathrm{bp}$ and $91 \mathrm{bp}$. If the sequence change $A T C>A C C$ is present, the site is lost and a single fragment of $361 \mathrm{bp}$ results. (B) Image of SfaNI restriction analysis of exon 3 of the MPZ gene in a selection of family members. An unaffected control member is shown in lane 1 and demonstrates the presence of $270 \mathrm{bp}$ fragment ( $91 \mathrm{bp}$ fragment not shown on gel). Lanes 2-8 represents imembers from the family as indicated. Each of these members demonstrates both uncut mutant allele $(361 \mathrm{bp})$ and cut normal allele $(270 \mathrm{bp})$. Lane 9 represents a size standard and lane 10, a non-restricted control.

erozygous change (ATC to ACC) in codon 99, resulting in the substitution of the isoleucine residue by a threonine residue. No other mobility shifts were detected in the $M P Z$ gene. The sequence change abolishes an SfaNI restriction site within the exon 3 fragment, allowing rapid screening of additional members. On restriction, a normal control allele demonstrates fragments of $270 \mathrm{bp}$ and $91 \mathrm{bp}$, and a mutant allele is represented by a $361 \mathrm{bp}$ fragment (fig 4). Other available affected family members $\left(\mathrm{II}_{1}, \mathrm{II}_{3}, \mathrm{II}_{6}, \mathrm{III}_{1}, \mathrm{III}_{2}, \mathrm{III}_{6}, \mathrm{III}_{7}, \mathrm{III}_{8}\right)$ were screened for the presence of the mutation by either direct sequencing or restriction analysis and were shown to possess the same heterozygous change at codon 99 . The change was not detected in 96 unrelated control alleles, as determined by SfaNI restriction analysis.

\section{Discussion}

The range of clinical and electrophysiological abnormalities associated with $M P Z$ mutations is expanding, and is summarised in table 2 . The members of this family present a new phenotypic range with some unusual features. If the members of the third generation had been seen alone, a label of HMSN II might have been attached to this pedigree. On the basis of conduction velocity alone, the proband and one of his sibs would be classified as HMSN1. However, the age at onset of symptoms, reported spontaneously only by members of the second generation and at no earlier than 50 years of age, is much later than that in most published reports of $M P Z$ mutation (less than 30 years of age in all reports except that of Ohnishi et $a l^{19}$; see table 2). The symptoms and signs of the affected family members, except $\mathrm{II}_{5}$, are also much milder than in almost all published reports. $^{6811121820-38}$ In keeping with this, motor conduction velocities in most published reports are much more severely reduced, usually less than $30 \mathrm{~m} / \mathrm{s}$; exceptions are the two recent reports of HMSN type II phenotypes in association with $M P Z$ mutation. ${ }^{15}{ }^{16}$ In addition, members in both second and third generations had positive sensory symptoms, whether volunteered or elicited at family interview. Positive sensory symptoms are not generally a feature of HMSN or other inherited neuropathies, although they have been reported in some progressive genetically determined storage disorders causing a secondary neuropathy such as metachromatic leukodystrophy and Krabbé's disease. ${ }^{39}$ The significance of the different ages of onset of symptoms in the second and third generations is not clear. The unique electroclinical phenotype of this pedigree may reflect the novelty of the $M P Z$ mutation.

All affected family members were heterozygous for the novel $M P Z$ mutation and it is curious that so many members of our pedigree have inherited the mutation. Although unlikely in purely statistical terms, other large pedigrees have provided the resource necessary for genetic studies of the inherited neuropathies, and even larger pedigrees are seen in association with mild phenotypes. ${ }^{16}$ The genetic alterations detected in such pedigrees, and our own, are not polymorphisms in the strict sense, but the resulting disease may be so mild as to have little apparent consequence on survival or reproductive fitness. The pattern of inheritance is dominant. The heterozygous sequence change identified in affected members of this family results in the substitution of the existing non-polar isoleucine residue by a threonine (uncharged polar) residue at codon 99. The isoleucine residue is conserved in human, bovine, and rat $M P Z$ proteins, but is replaced by other non-polar residues (methionine and valine) in chicken and shark $M P Z$ proteins respectively. Taken in combination with the finding that the change was not seen in 96 unrelated control alleles, it suggests that this sequence change is responsible for the phenotype in this family.

$M P Z$ is considered to have a major role in the compaction of normal myelin via homophilic interactions mediated by a single extracellular Ig-like domain ${ }^{40} 41$ and its associated N-linked carbohydrate moiety. Similar adhesive qualities are also mediated by homophilic interactions of the intracellular domains and their interaction with membrane phospholipids. ${ }^{42}$ These hypotheses are supported by the generation of various $M P Z$ knockout mouse models that 
demonstrate poor myelin compaction, accompanied by axon degeneration and signs of demyelination. ${ }^{43-46}$ Codon 99 resides in exon 3 of the $M P Z$ gene, and with exon 2 makes up the extracellular domain of the protein. Most mutations reported to date occur in either exon 2 or 3 or the $M P Z$ gene, indicating the importance of this domain in normal $M P Z$ function (table 2). Evidence from the nerve biopsy of member $\mathrm{II}_{3}$, combined with the general family phenotype, indicates that the effect of this codon 99 mutation in this family is rather mild. This is by contrast with the effect of mutations at the adjacent amino acid: arg98pro, arg98cys, and arg98his, resulting in phenotypes that range from the classic Charcot-Marie-Tooth disease type 1 to Déjerine-Sottas disease. Nerve pathology confirmed that defective myelination was evident in those cases and widening of the myelin intraperiod lines was also a common finding. The apparent severity of mutation at this adjacent codon contrasts with the mild phenotype noted in the family described here.

Given the occurrence of CIDP-like illness in the proband, does this $M P Z$ mutation predispose to inflammatory neuropathy? Interestingly, heterozygous $\mathrm{P}_{0}$ knockout mice develop a neuropathy resembling CIDP, with an age dependent onset, and progression to a variable level of disability with subsequent stabilisation. Electrophysiological features of CIDP were noted with temporal dispersion, non-uniform slowing, and conduction block. Progressive morphological changes in initially normal appearing nerves, onion bulb formation, and axonal loss were also noted accompanied by $\mathrm{T}$ lymphocyte and macrophage infiltration. These findings led to speculation that an immune mediated mechanism contributes to

Table 2 Summary of previous reports of MPZ mutations

\begin{tabular}{|c|c|c|c|c|}
\hline First author/reference & Mutation & $\begin{array}{l}\text { Age at onset (y) } \\
\text { (proband) }\end{array}$ & $\begin{array}{l}\text { Median motor conduction } \\
\text { velocity in } \mathrm{m} / \mathrm{s} \text { (ulnar) }\end{array}$ & Phenotype \\
\hline Kulkens $(1993)^{24}$ & $\operatorname{Ser}(63) \mathrm{del}$ & Youngest studied, 4 & $<25$ s & CMT1 \\
\hline \multirow[t]{2}{*}{ Hayasaka $(1993)^{30}$} & Ser(63)Cys & $2 \dagger$ & $(6.7)$ & DSS \\
\hline & Gly(167)Arg & 3 & 10 & DSS \\
\hline \multirow[t]{2}{*}{ Hayasaka $(1993)^{31}$} & Lys (96)Glu & $4 \$$ & $<20 \$$ & CMT1 \\
\hline & Asp (90)Glu & - & $<380$ & CMT1 \\
\hline Hayasaka $(1993)^{32}$ & $\operatorname{Ile}(30) \mathrm{Met}$ & $<3$ & - & CMT1 \\
\hline Hayasaka $(1993)^{33}$ & $\mathrm{Arg}(98) \mathrm{His}$ & 25 & 19.4 & CMT1 \\
\hline Himoro $(1993)^{38}$ & $\operatorname{Tyr}(82)$ Cys & 16 & 11 & CMT1 \\
\hline Mitsui $(1994)^{21}$ & $\operatorname{Tyr}(245)$ Cys & 13 & "Markedly delayed" & CMT1 \\
\hline Nelis $(1994 a)^{18}$ & Asp (134)Glu & - & Mean 13.1 & CMT1 \\
\hline \multirow[t]{4}{*}{ Nelis $(1994 b)^{52}$} & $\operatorname{Ser}(78) \mathrm{Leu}$ & - & - & CMT1 \\
\hline & Asp(134)Asn & & & \\
\hline & $\operatorname{Tyr}(154)$ stop & & & \\
\hline & $\operatorname{Tyr}(181)$ stop & & & \\
\hline Rautenstrauss $(1994)^{4}$ & $\mathrm{Ala}(221) \mathrm{fs}$ & $<4$ & 15 & DSS \\
\hline \multirow[t]{2}{*}{$\mathrm{Su}(1993)^{26}$} & Lys (96)Glu & $4 \rrbracket$ & $<20 \Omega$ & CMT1 \\
\hline & $\operatorname{Thr}(96)$ Arg-Glu & - & $<380$ & \\
\hline Blanquet-Grossard $(1995)^{23}$ & Ser(63)Phe & At age of walking & 13 & CMT1 \\
\hline Latour $(1995)^{29}$ & $\operatorname{Trp}(101)$ Cys & Childhood & 10 & CMT1 \\
\hline Bellone $(1996)^{13}$ & $\operatorname{Val}(232) \mathrm{fs}$ & $14 \sqrt{4}$ & 215 & CMT \\
\hline Blanquet-Grossard $(1996)^{9}$ & $\operatorname{Asp}(122)$ Ser & 44 & 32 & CMT1 \\
\hline \multirow[t]{4}{*}{ Gabreels-Festen $(1996)^{5}$} & $\operatorname{Arg}(98) \mathrm{His}$ & $1.8 \ddagger$ & 19 & DSS \\
\hline & Lys(130)Arg & $2.5 \ddagger$ & 11 & DSS \\
\hline & Ile(135)Leu & $2.5 \ddagger$ & 7 & DSS \\
\hline & $\operatorname{Arg}(98)$ Cys & no & (8.5) & $\mathrm{CH}$ \\
\hline Ikegami $(1996)^{6}$ & Phe(64) deletion* & 11 & - & DSS \\
\hline \multirow{2}{*}{ Meijerink $(1996)^{22}$} & $\operatorname{Arg}(69) \mathrm{His}$ & 2 & 19 & CMT1 \\
\hline & $\operatorname{Arg}(69)$ Cys & 6 Months & (8.5) & CMT1 \\
\hline Ohnishi $(1996)^{19}$ & $\operatorname{Arg}(98) \mathrm{His}$ & 46 & 14.8 & CMT1 \\
\hline \multirow[t]{2}{*}{ Roa $(1996 a)^{35}$} & Met(69)Lys & 18 & (3.3) & CMT1 \\
\hline & Ser(72)Leu & 8 & 21 & CMT1 \\
\hline \multirow[t]{2}{*}{$\operatorname{Roa}(1996 b)^{36}$} & $\mathrm{Ile}(135) \mathrm{Thr}$ & 12 & 15 & CMT1 \\
\hline & Gly(137)Ser & 22 & 13 & CMT1 \\
\hline \multirow[t]{3}{*}{ Rouger $(1996)^{27}$} & Arg(98)Pro & - & $19.6 \rrbracket$ & CMT1 \\
\hline & $\operatorname{Arg}(98)$ Cys & 1 & 9 & CMT1 \\
\hline & $\operatorname{Arg}(98) \mathrm{His}$ & - & - & CMT1 \\
\hline \multirow[t]{3}{*}{ Silander $(1996)^{37}$} & Gly Pro Tyr & 1 & 10 & DSS \\
\hline & Ile $(86-89)$ to & & & \\
\hline & His Leu Phe & & & \\
\hline Tachi $(1996)^{34}$ & Lys(131)Arg & 7 & (7.3) & CMT1 \\
\hline \multirow[t]{6}{*}{ Warner $(1996)^{8}$} & $\operatorname{Arg}(98)$ Ser & 3 & 11 & CMT \\
\hline & $\operatorname{Arg}(98)$ Cys & Infancy† & $(6.1)$ & DSS \\
\hline & Leu(174) fs & Infancy & not stated & DSS \\
\hline & $\operatorname{Gly}(103) \mathrm{fs}^{\star}$ & Infancy & absent & DSS \\
\hline & Gly (103) fs & Not stated & $33.6-47.1$ & CMT \\
\hline & $\mathrm{Gln}(215)$ stop & Infancy & 6 & $\mathrm{CH}$ \\
\hline \multirow[t]{5}{*}{ Bort $(1997)^{10}$} & Ser(78)Leu & - & - & CMT1 \\
\hline & $\operatorname{Arg}(98)$ Cys & - & - & DSS \\
\hline & splice site & - & - & CMT- \\
\hline & fs & - & - & CMT1 \\
\hline & $\mathrm{fs}$ & - & - & CMT- \\
\hline \multirow[t]{4}{*}{ Warner $(1997)^{12}$} & Ile(114)Thr; & 9 Weeks & 8 & DSS \\
\hline & Asn (116)His; & & & \\
\hline & Asp(128)Asn & & & \\
\hline & all in same allele & & & \\
\hline De Jonghe $(1998)^{15}$ & $\operatorname{Thr}(124) \mathrm{Met}$ & $>30 \$$ & range $24-59$ & СMT2 \\
\hline Marrosu $(1998)^{16}$ & Ser(44)Phe & $38-625$ & mean 42.3 & CMT2 \\
\hline Tachi $(1998)^{14}$ & Premature stop & Neonatal $\dagger$ & (3) & $\mathrm{CH}$ \\
\hline
\end{tabular}

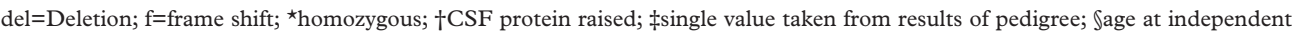
walking; $=$ not given or not estimated. 
the demyelination in these animals. Acute inflammatory neuropathy has been found in Charcot-Marie-Tooth disease associated with a reduplication of the PMP22 gene. ${ }^{47}$ Mixed electrophysiological features of both hereditary and acquired demyelinating neuropathy have been described in X-linked Charcot-MarieTooth disease associated with connexin 32 mutations, which too can show clinical progression. ${ }^{48}$ Our family and others in the literature have some features of this animal model with progression and evidence of inflammation. Whether this is triggered by the abnormal myelin constituents or an autoimmune response to myelin is unclear but suggests that other factors have a role in the expression of the basic genetic defect.

The proband and $\mathrm{II}_{3}$ had more severe and disabling symptoms, and clinical evidence of motor progression not ascribable to orthopaedic complications. Both had raised CSF protein. There are other reports of progressive symptoms in pedigrees with $M P Z$ mutation, sometimes occurring for a limited period. ${ }^{18}$ Steroid responsiveness has been reported in cases of progressive HMSN, usually characterised by increased CSF protein. ${ }^{50}$ The steroid therapy given to the proband in our family was of undoubted initial benefit, although to a lesser eventual degree than in many patients with sensory-motor chronic CIDP. Only long term follow up will determine whether all carriers of this mutation undergo accelerated deterioration partially responsive to steroids. The presence of CIDP in two siblings has also been reported. ${ }^{51}$ That report predated molecular genetic testing in HMSN, leaving open the possibility that the siblings in fact had a genetically determined (predisposition to) neuropathy. This raises the question of whether other familial, or even some apparently sporadic cases of CIDP ought to be tested for known HMSN mutations.

The Medical Genetics Laboratory is a member of the European CMT Consortium, which is sponsored by a EU
BIOMED2 grant (CT951614). We are grateful to Mrs J BIOMED2 grant (CT951614). We
Wilkinson for preparing the manuscript.

1 Harding AE. From the syndrome of Charcot, Marie and Tooth to disorders of peripheral myelin proteins. Brain 1995;118:809-18.

2 Snipes GJ, Suter U. Molecular anatomy and genetics of myelin proteins in the peripheral nervous system. F Anat 1995; 186:483-94.

3 Hayasaka K, Himoro M, Sato W, et al. Charcot-MarieTooth neuropathy type $1 \mathrm{~B}$ is associated with mutations of the myelin $\mathrm{P}_{0}$ gene. Nat Genet 1993;5:31-34.

4 Rautenstrau $\beta$ B, Nelis E, Grehl H, et al. Identification of a de novo insertional mutation in $\mathrm{P}_{0}$ in a patient with a de novo insertional mutation in $\mathrm{P}_{0}$ in a patient with a
Déjérine-Sottas syndrome (DSS) phenotype. Hum Mol Déjérine-Sottas syndron $1994 ; 3: 1701-2$.

5 Gabreëls-Festen AAWM, Hoogendijk JE, Meijerink PHS, et al. Two divergent types of nerve pathology in patients with different $\mathrm{P}_{0}$ mutations. Neurology 1996;47:761-5.

6 Ikegami T, Nicholson G, Ikeda H, et al. A novel homozygous mutation of the myelin $\mathrm{P}_{0}$ gene producing Déjérine-Sottas disease (hereditary motor and sensory neuropathy type III). Biochem Biophys Res Commun 1996;222:107-10.

7 Silander K, Meretoja P, Nelis E, et al. A de novo duplication in $17 \mathrm{p} 11.2$ and a novel mutation in the $\mathrm{P}_{0}$ gene in two Déjérine-Sottas syndrome patients. Hum Mutat 1996;8: 304-10.

8 Warner LE, Hilz MJ, Appel SL, et al. Clinical phenotypes of different $M P Z\left(\mathrm{P}_{0}\right)$ mutations may include Charcot-MarieTooth type 1B, Déjérine-Sottas, and congenital hypomyelination. Neuron 1996;17:451-60.

9 Blanquet-Grossard F, Pham-Dinh D, Dautigny A, et al. Blanquet-Grossard F, Pham-Dinh D, Dautigny A, et al. the single glycosylation site in the major peripheral myelin glycoprotein $\mathrm{P}_{0}$. Hum Mutat 1996;8:185-6.
10 Bort S, Nelis E, Timmerman V, et al. Mutational analysis of the $M P Z, \mathrm{PMP} 22$ and $\mathrm{C} \times 32$ genes in patients of Spanish ancestry with Charcot-Marie-Tooth disease and hereditary neuropathy with liability to pressure palsies. Hum Genet 1997;99:746-54

11 Tyson J, Ellis D, Fairbrother U, et al. Hereditary demyelinating neuropathy of infancy. A genetically complex syndrome. Brain 1997;120:47-63.

12 Warner LE, Shohat M, Shorer Z, et al. Multiple de novo $M P Z\left(\mathrm{P}_{0}\right)$ point mutations in a sporadic Dejerine-Sottas case. Hum Mutat 1997;10:21-4.

13 Bellone E, Mandich P, James R, et al. Identification of a 4 bp deletion (1560del4) in $\mathrm{P}_{0}$ gene in a family with severe Charcot-Marie-Tooth disease. Hum Mutat 1996;7:377-8.

14 Tachi N, Kozuka N, Ohya K, et al. A small direct tandem duplication of the myelin protein zero gene in a patient with Déjérine-Sottas disease phenotype. F Neurol Sci 1998;156: 167-71.

15 De Jonghe P, Timmerman V, Ceuterick C, et al. A novel peripheral myelin zero $(M P Z)$ mutation is associated with a clinically distinct Charcot-Marie-Tooth type 2 phenotype. 7 Neurol 1998;245:352.

16 Marrosu MG, Vaccargiu S, Marrosu G, et al. CharcotMarie-Tooth disease type 2 associated with mutation of the myelin protein zero gene. Neurology 1998;50:1397-401.

17 Kennett RP. Nerve conduction and electromyography. Medicine 1996;24:26-8.

18 Nelis E, Timmerman V, De Jonghe P, et al. Linkage and mutation analysis in an extended family with CharcotMarie-Tooth disease type 1B. F Med Genet 1994;31:81115.

19 Ohnishi A, Kashiwada E, Hashimoto T, et al. A family of hereditary motor and sensory neuropathy type I with a mutation (Arg98->His) in myelin Po-report on a second Japanese family. Sangyo Ika Daigaku Zasshi 1996;18:19-29.

20 Birouk N, Gouider R, Le Guern E, et al. Charcot Marie Birouk N, Gouider R, Le Guern E, et al. Charcot Marie
Tooth disease type 1A with 17p11.2 duplication. Clinical and electrophysiological phenotype study and factors influencing disease severity in 119 cases. Brain 1997;120:81323.

21 Mitsui Y, Matsui T, Nakamura Y, et al. A familial Charcot Marie Tooth disease type 1B (CMTD1B) manifesting a new mutation of myelin $\mathrm{P}_{0}$ gene. Rinsho Shinkeigaku 1994; 34:1162-7.

22 Meijerink PH, Hoogendijk JE, Gabreels-Festen AA, et al. Clinically distinct codon 69 mutations in major myelin protein zero in demyelinating neuropathies. Ann Neurol 1996;40:672-5.

23 Blanquet-Grossard F, Pham-Dinh D, Dautigny A, et al. Charcot Marie Tooth type 1B neuropathy: third mutation of serine 63 codon in the major peripheral myelin glycoprotein $\mathrm{P}_{0}$ gene. Clin Genet 1995;48:281-3.

24 Kulkens T, Bolhuis PA, Wolterman RA, et al. Deletion of the serine 34 codon from the major peripheral myelin protein $\mathrm{P}_{0}$ gene in Charcot-Marie-Tooth disease type 1B. Nat Genet 1993;5:35-9.

25 Tachi N, Ishikawa Y, Minami R. Two cases of congenital hypomyelination neuropathy. Brain Dev 1984;6:560-5.

$26 \mathrm{Su}$ Y, Brooks DG, Li L, et al. Myelin protein zero gene mutated in Charcot-Marie-Tooth type 1B patients. Proc Natl Acad Sci USA 1993;90:10856-60.

27 Rouger H, LeGuern E, Gouider R, et al. High frequency of mutations in codon 98 of the peripheral myelin protein $\mathrm{P}_{0}$ gene in 20 French CMT1 patients [letter]. Am $\mathcal{F}$ Hum Genet 1996;58:638-41

28 Sorour E, MacMillan J, Upadhyaya M. Novel mutation of the myelin $\mathrm{P}_{0}$ gene in a CMT1B family. Hum Mutat 1997; 9:74-7.

29 Latour P, Blanquet F, Nelis E, et al. Mutations in the myelin protein zero gene associated with Charcot-Marie-Tooth disease type 1B. Hum Mutat 1995;6:50-4.

30 Hayasaka K, Himoro M, Sawaishi Y, et al. De novo mutation of myelin $\mathrm{P}_{0}$ gene in Dejerine Sottas disease (hereditary of myelin $\mathrm{P}_{0}$ gene in Dejerine Sottas disease (hereditary motor 266 .

31 Hayasaka K, Himoro M, Sato W, et al. Charcot Marie Tooth neuropathy type $1 \mathrm{~B}$ is associated with mutations of the myelin $\mathrm{P}_{0}$ gene. Nat Genet 1993;5:31-4.

32 Hayasaka K, Takada G, Ionasescu VV. Mutation of the myelin $\mathrm{P}_{0}$ gene in Charcot Marie Tooth neuropathy type 1B. Hum Mol Genet 1993;2:1369-72.

33 Hayasaka K, Ohnishi A, Takada G, et al. Mutation of the myelin $\mathrm{P}_{0}$ gene in Charcot Marie tooth neuropathy type 1 . Biochem Biophys Res Commun 1993;194:1317-22.

34 Tachi N, Kozuka N, Ohya K, et al. A new mutation of the $P_{0}$ gene in patients with Charcot-Marie-Tooth disease type gene in patients with Charcot-Marie-Tooth disease type
1B: screening of the $\mathrm{P}_{0}$ gene by heteroduplex analysis [let1B: screening of the $\mathrm{P}_{0}$ gene by

35 Roa BB, Warner LE, Garcia CA, et al. Myelin protein zero $(M P Z)$ gene mutations in nonduplication type 1 CharcotMarie-Tooth disease. Hum Mutat 1996a;7:36-45.

36 Roa BB, Greenberg F, Gunaratne P, et al. Duplication of the PMP22 gene in 17p partial trisomy patients with Charcot Marie Tooth type 1 neuropathy. Hum Genet 1996;97:6429.

37 Silander K, Meretoja P, Nelis E, et al. A de novo duplication in $17 \mathrm{p} 11.2$ and a novel mutation in the $\mathrm{P}_{0}$ gene in two Déjérine-Sottas syndrome patients. Hum Mutat 1996;8: 304-10.

38 Himoro $M$, Yoshikawa $\mathrm{H}$, Matsui $\mathrm{T}$, et al. New mutation of the myelin $\mathrm{P}_{0}$ gene in a pedigree of Charcot-Marie-Tooth neuropathy type 1. Biochem Mol Biol Int 1993;31:169-73. 
39 Donaghy M. Disorders of peripheral nerves. In: Walton ed. Brain's diseases of the nervous system, 10th ed. Oxford: Oxford Brain's diseases of the nervous system,
University Press, 1993:555-624.

40 Spiryda LB. Myelin protein zero and membrane adhesion. $\mathcal{F}$ Neurosci Res 1998;54:137-46.

41 Zhang K, Merazga Y, Filbin MT. Mapping the adhesive domains of the myelin $\mathrm{P}_{0}$ protein. $\mathcal{F}$ Neurosci Res 1996;45:525-33.

42 Neuberg DH, Carenini S, Schachner M, et al. Accelerated demyelination of peripheral nerves in mice deficient in connexin 32 and protein zero. $\mathcal{F}$ Neurosci Res 1998;53:54250.

43 Guenard V, Montag D, Schachner M, et al. Onion bulb cells in mice deficient for myelin genes share molecular properties with immature, differentiated non-myelinating, and denervated Schwann cells. Glia 1996;18:27-38.

44 Zielasek J, Martini R, Toyka KV. Functional abnormalities in $\mathrm{P}_{0}$-deficient mice resemble human hereditary neuropathies linked to $\mathrm{P}_{0}$ gene mutations. Muscle Nerve 1996;19. 946-52.

45 Martini R, Zielasek J, Toyka KV, et al. Protein zero $\left(\mathrm{P}_{0}\right)$-deficient mice show myelin degeneration in peripheral nerves characteristic of inherited human neuropathies. Nat Genet 1995;11:281-6.
46 Shy ME, Arroyo E, Sladky J, et al. Heterozygous P knockout mice develop a peripheral neuropathy that resembles chronic inflammatory demyelinating polyneuropathy (CIDP). I Neuropathol Exp Neurol 1997;56:811-21.

47 Malandrini A, Villanova M, Dotti MT, et al. Acute inflammatory neuropathy in Charcot-Marie-Tooth disease. Neurology 1999;52:859-61.

48 Tabaraud F, Lagrange E, Sindou P, et al. Demyelinating $\mathrm{X}$-linked Charcot-Marie-Tooth disease: unusual electrophysiological findings. Muscle Nerve 1999;22:1442-7.

49 Gutierrez A, England JD, Sumner AJ, et al. Unusual electrophysiological findings in X-linked dominant CharcotMarie-Tooth disease. Muscle Nerve 2000;23:182-8.

50 Dyck PJ, Swanson CJ, Low PA, et al. Prednisone-responsive hereditary motor and sensory neuropathy. Mayo Clin Proc 1982;57:239-46.

51 Gabreëls-Festen AAWM, Hageman ATM, Gabreëls FJM, et al. Chronic inflammatory demyelinating polyneuropathy in two siblings. F Neurol Neurosurg Psychiatry 1986;49:152-6.

52 Nelis E, Timmerman V, De Jonghe P, et al. Rapid screening of myelin genes in CMT1 patients by SSCP analysis: identification of new mutations and polymorphisms in the $\mathrm{P}_{0}$ gene. Hum Genet 1994;94:653-7. 